\title{
The Role of Court Representatives in Cost Calculation of Bankruptcy Proceedings: A Case From Poland
}

\author{
Kinga Bauer \\ Cracow University of Economics, Cracow, Poland
}

\begin{abstract}
Bankruptcies of enterprises not only in Poland, but also in other countries throughout the world, are still an insufficiently recognized phenomenon. In practice, bankruptcy is associated with the measurement of values resulting from economic categories, for example, costs. Bankruptcy proceedings costs are generated during all insolvency systems all over the world. The costs are covered mainly by the bankruptcy estate. In Poland, it is the responsibility of the court representative to prepare analyses of proceedings' costs. Information about the amount of costs of proceedings in comparison to bankruptcy estate affects the court's decision to declare bankruptcy. Therefore, the reliability and transparency of the cost calculation of bankruptcy proceedings are important in the bankruptcy process and can help to minimize social costs of bankruptcies. This paper is a theoretical and practical analysis of issues related to the role of court representatives in the analysis of bankruptcy costs in Poland. The research has shown that the practice of cost calculation during bankruptcy proceedings in Poland complies with the requirements of the Polish Bankruptcy and Reorganization Law, however, it does not utilize information possibilities coming from the application of cost accounting. The paper includes proposed directions of change for the analyzed issue.
\end{abstract}

Keywords: costs of bankruptcy proceedings, insolvency, court representatives, Poland

Bankruptcy of enterprises is an integral part of the market economy. In transition economies, for example, in Poland, research on bankruptcy of enterprises is a fairly new field. Bankruptcy Law and laws for arrangement proceedings have been in place in Poland since 1934. However, after 1945, during times of a centralized market, the idea of bankruptcy did not exist. Unprofitable enterprises were funded by the state. The new Bankruptcy and Reorganization Law has been in effect since 2003, and is subject to continuous amendments.

Research indicates that in Poland, there is still a little knowledge about economical aspects of bankruptcy (Mączyńska, 2008) and problems with the quality of financial information that could serve as a basis for assessment of the going concern risk (Wędzki, 2012). This limited knowledge about bankruptcy of enterprises, as stated by Maczyńska (2008), in practice leads to "An attempt to square the circle: Bankruptcies are insufficiently diagnosed, due to - but not only - the underdevelopment of the institutional infrastructure of bankruptcy, and this underdevelopment, in turn, is an additional factor of bankruptcy risk" (Maczyńska, 2008, p. 11).

Corresponding author: Kinga Bauer, Ph.D., assistant professor, Department of Accounting, Cracow University of Economics; research fields: financial and managerial accounting, financial reporting, financial analysis, limitations and possibilities of using accounting in insolvency proceedings, accounting and financial reporting in SME sector. E-mail: kinga.bauer@uek.krakow.pl. 
Lacking of sufficient knowledge, regulatory weaknesses, and problems of practice in the field of bankruptcy are noticeable not only in Poland but also in other European Union (EU) countries and the world (Mączyńska, 2008). According to Stiglitz (2004), bankruptcy codes are not well diagnosed from the economic perspective.

Bankruptcy of enterprises is strongly associated with incurring the costs of bankruptcy. Due to the inability to completely eliminate the phenomenon of bankruptcies, it is important to strive to minimize the costs of bankruptcy, including those associated with conducting the proceedings.

Bankruptcy costs are one of the major financial categories, the measurements of which should be taken during bankruptcy proceedings. Of particular importance is the analysis of the costs of a bankruptcy trial, carried out in the initial stage of the proceedings. In Poland, the responsibility for carrying out the analysis of the costs of the bankruptcy proceedings rests with the representatives of the court. Reliability of the analyses conducted by court representatives has an impact on the court's decision about the future of a debtor's enterprise.

The ideas included in this paper are based on the belief that minimization of the costs of bankruptcy proceedings requires their prior analysis and fairly conducted estimates, taking into account the impact of changes that might occur in the environment of the bankrupt enterprise. Cost accounting theory shows that efficiency of an analysis requires a comparison of actual and planned costs.

The aim of this paper is to analyze the theoretical and practical issues related to the role of court representatives in the analysis of bankruptcy proceedings' costs in Poland. It was assumed that the significant role of court representatives in cost calculation involves the appointment by the court of interim court supervisors to estimate the cost of bankruptcy. In view of the possibility for the court to choose different types of bankruptcy proceedings, a decisive cost accounting is more important if it is made in two versions (for bankruptcy proceedings leading to make an arrangement and to liquidate the assets of the insolvent debtor). Transparency of cost calculations needs to relate them to the revenue side and to divide them into sub-periods. Furthermore, as follows from the theory of cost accounting, cost analysis is significant if during the final stage, the actual costs are compared with planned costs, and explanations of reasons for deviations are provided. The role of court representatives in cost calculations in Poland, was determined by a quantitative analysis of the work of court representatives on the above-mentioned aspects.

In this paper, the state of existing research and the legal basis for the analysis of the costs of bankruptcy proceedings have been discussed. The results of the author's own research on the issue have been presented. The research was conducted on a sample of 100 companies, on which the court declared bankruptcy in 2011. The sample accounts for $14 \%$ of the population and is an important representative of the phenomenon in the country. In addition, included in the paper are proposals of changes to the analysis of bankruptcy proceedings costs, as it is one of the grounds for action for the court when making the decision to declare bankruptcy in an enterprise.

\section{The Essence of Cost Calculation of Bankruptcy Proceedings}

The research on the calculation of costs of bankruptcy proceedings is not new in countries with a developed market economy. The research relates to analyses associated with the measurement of cost amounts, methods of distribution into different categories of costs, and their use as measures of effectiveness of bankruptcy systems and procedures (Gruber \& Warner, 1977; Warner \& White, 1983; Altman, 1984; Skeel Jr, 1993; Hennessy \& Whited, 2007; Newton, 2010). 
Interest in bankruptcy costs rises from the fact that in all bankruptcy systems worldwide, the bankruptcy proceedings are associated with costs. Marsh (2010) commented on the bankruptcy costs in the United Kingdom, wrote explicitly that: "It is ironic, but it is quite expensive to go bankrupt" (Marsh, 2010, p. 45). Initiating bankruptcy proceedings entail advance payments toward the costs of bankruptcy proceedings (Finch, 2012). Where the estimated bankruptcy costs exceed the value of the bankrupt enterprise's assets, this results in dissolution of the company, not the bankruptcy (Altman \& Hotchkiss, 2006). In Poland, the court shall dismiss the petition to declare bankruptcy when the assets of the insolvent debtor are not sufficient to cover the cost of the proceedings.

In accordance with Smith and Strömberg (2004), bankruptcy proceedings involve costs, both directly related to the bankruptcy procedure and indirect ones, e.g., impairment of assets. In their opinion, bankruptcy law should support the effectiveness of the bankruptcy proceedings, i.e., facilitate a quick conclusion of an agreement between the debtor and the creditors. Faster bankruptcy proceedings limit the procedural costs as well as reduce the losses resulting from a decrease in the liquidation value of the bankrupt's assets.

Bankruptcy proceedings costs are also high in Poland. In addition to the costs associated with running the insolvency proceedings, the cost of liquidating the company is also associated with the loss of jobs, the devaluation of the technical infrastructure, and the know-how. Efforts are being made to reduce these costs by changing the law and facilitating the restructuring of enterprises (Płoch, Groele, \& Geromin, 2013) and introducing - for the debtors - the possibility of applying for exemptions from court fees in bankruptcy proceedings.

From 2013, debtors who can prove that they are not able to bear the legal costs without detriment to themselves or their family or do not have sufficient funds to cover such costs, may apply to be exempt from these costs. Regardless of the efforts to reduce these costs, they are still an important factor for the court when making the decision regarding the fate of the company, and their analysis in the initial stage of the proceedings may have an impact on the effectiveness of conducting a proper trial.

The costs of bankruptcy are a broader concept than the costs of the insolvency proceedings. Chłodnicka (2005) defines costs of bankruptcy as:

Probable decrease in economic benefits which are of fixed value during a reporting period, causing weakening of the financial situation of an enterprise, that in turn creates additional burdens which determine the future of the bankruptcy process. The burdens take on the form of a reduction in the value of assets or an increase of liabilities or reserves. (Chłodnicka, 2005, p. 115)

Research on the costs of bankruptcy is focused mainly on the analysis by direct costs (associated with legal proceedings and bankruptcy) and indirect ones (i.e., unearned or lost profits as a result of the initiation of proceedings leading to liquidation of the debtor's assets) (Prusak, 2011). Research calculations included the mean and median in relation to the book value of assets of the company in debt or its market value before bankruptcy (Altman \& Hotchkiss, 2006). Research conducted in Poland shows that in the process of bankruptcy, it is more appropriate to compare the costs of the trial with the estimated value of the debtor's assets. This is justified by both the law and practice of bankruptcy proceedings, in which the basis for the decision to declare bankruptcy is a reference to the estimated value of the debtor's assets (Bauer, 2013a).

The costs of the bankruptcy proceedings, in accordance with applicable law and the logic of the bankruptcy proceedings are divided into the following costs: (1) preparatory (reconnaissance); and (2) the actual bankruptcy trail. 
These costs can be assigned to various sections. Chłodnicka (2004) has assigned them based on task:

(1) The cost of core bankruptcy operations, this includes the valuation of assets, conducing an auction, employee compensation (including charges like allowances, taxes, etc.), severance, penalties, damages, fines, bailiffs activities, taxes and donations, etc.;

(2) The costs of administrative activities during bankruptcy, including the remuneration of the liquidator, the board of creditors, employees hired to fulfill all necessary tasks during the bankruptcy process, the costs of notices and announcements, and other administrative costs;

(3) Finance expenses, including interest on debt, judicial interest, administrative, etc.

The costs of bankruptcy should be presented within the framework of cost accounting. Cost accounting is a modern tool of management accounting which, at the time of bankruptcy proceedings, allows you to reduce costs to a level necessary to properly conduct the proceedings. Its correct use can affect the fulfillment of creditors' claims to a greater degree than if it was not used at all (Sojak \& Trojanek, 2010).

Despite the significance of bankruptcy costs, research virtually ignores the role of individuals responsible for the quality of the above-mentioned analyses. Legislation related to bankruptcy focuses on the obligations associated with cost calculations.

\section{Legal Basis for Cost Calculation of Bankruptcy Proceedings in Poland}

Bankruptcy is to protect creditors, so that at least partially - they regain their debts. The law is to guarantee this protection, with regulations that foster discipline and integrity in financial management of an enterprise where bankruptcy proceedings are being conducted (Wessels, Markell, \& Kilborn, 2009). One element of the bankruptcy proceedings documentation, created to provide information necessary for the court to make a decision to declare bankruptcy and to select its kind, is an analysis of costs of the bankruptcy proceedings. This analysis is created in the period between the filing of the request to declare bankruptcy and the court's decision to initiate bankruptcy proceedings or dismiss the claim.

The responsibility for the analysis of the cost of bankruptcy proceedings in Poland rests with the representatives of the court, i.e.:

(1) During proceedings on declaring bankruptcy—interim court supervisor or interim administrator;

(2) During bankruptcy operations - court supervisor, administrator, or trustee.

Their analyses are evaluated by a judge — commissioner and professional judges.

In accordance with Art. 168, interim court supervisor (or interim administrator) prepares periodical reports on their activities and financial reports with justification. One of the elements of these reports is the analysis of the costs of the bankruptcy proceedings conducted ex ante, for the period between declaring bankruptcy and concluding bankruptcy proceedings. The purpose of this analysis enables the court to make a decision regarding the declaration of bankruptcy. This is due to the fact that, in accordance with Art. 13 (para. 1), the court shall dismiss the petition to declare bankruptcy when the assets of the insolvent debtor are not sufficient to cover the cost of the proceedings.

The terminology of the Polish Bankruptcy and Reorganization Law is not consistent with accounting concepts. Art. 230 is vague when it comes to the use of the terms "costs" and "expenses" (Tokarski, 2010). In the preparation of accounting statements by court representatives for the purpose of bankruptcy proceedings, accounting principles are not applied. This can be the reason that these terms are used interchangeably, and the moment that the expenditure is made associated with the moment of incurring a cost. 
The costs of bankruptcy proceedings shall include court fees and expenses necessary to achieve the purpose of the proceedings, that is:

(1) Remuneration and expenses of the trustee, court supervisor and administrator, as well as their deputies;

(2) Remuneration and expenses related to creditors' meeting;

(3) Costs of service, announcements, and notices;

(4) Taxes and other public levies due for the period following the declaration of bankruptcy;

(5) Expenses connected with the administration of the bankruptcy estate;

(6) Expenses connected to liquidation of the bankruptcy estate.

Moreover, in accordance with Art. 185, the cost of bankruptcy proceedings also includes costs connected with the operation of the bankrupt's authorities and the exercising of the bankrupt's corporate rights, that is, in particular the costs to (Jakubecki \& Zedler, 2010):

(1) Convene a general meeting of shareholders or stockholders;

(2) Appoint governing bodies of the enterprise undergoing bankruptcy and report this selection to the National Court Register;

(3) Costs of office supplies essential for the operations of the bankrupt, etc.

The Bankruptcy and Restructuring Law does not contain a closed list of expenses, and only mentions examples. The costs of the bankruptcy proceedings include all the essential expenses that are necessary to conduct the bankruptcy proceedings (Jakubecki \& Zedler, 2010).

The purpose of bankruptcy proceedings is not just liquidation of the bankruptcy estate, but also to satisfy, even if to a minimal degree, the claims of creditors (Jakubecki \& Zedler, 2010). Therefore, cost analyses of bankruptcy proceedings refer not only to the liquidation of the bankruptcy estate, but also the possibility to cover creditors' claims.

The ability to cover these costs is assigned to the income side, i.e., from the bankruptcy estate funds, which includes funds received from the liquidation of the bankruptcy estate or other sources (e.g., income from business activities, leasing of the bankrupt company and interest earned in the bank).

It is the duty of court representatives to analyze whether the costs of bankruptcy were carried out according to the estimates. The representative is to monitor this from the moment when bankruptcy is declared until all bankruptcy proceedings are finalized. An analysis of the actual costs is a part of periodic statements of accounts prepared by representatives of the court.

In summary, the costs of bankruptcy proceedings are incurred both in the initial stage of bankruptcy proceedings (the so-called reconnaissance costs), and during the actual bankruptcy proceedings. Ex ante analysis prepared by the provisional court supervisor in the initial bankruptcy proceedings refers to the costs of the actual proceedings, and it provides a base on which the court makes a decision to declare bankruptcy.

In view of the fact that the costs of bankruptcy proceedings are one of the main financial categories used by the court when deciding about the future of an enterprise in debt, it is absolutely crucial for the estimates to be conducted in a reliable manner and not to differ significantly from the costs incurred.

\section{The Practice of Cost Calculations of Bankruptcy Proceedings in Poland}

\section{Results of the Latest Research on Costs of Bankruptcy Proceedings}

In Poland, research concerning the loss of ability to continue business operations mainly focuses on forecasting bankruptcy of enterprises and the subject of bankruptcy proceedings, as an economic process, 
including the costs associated with bankruptcy, is rarely taken up.

Studies about forecasting bankruptcy were conducted by: Waśniewski and Skoczylas, Mączyńska, Gajdka, Stos, Hadasik, Appenzeler and Szarzec, Wędzki, Hołda, Prusak, Hamrol, Czajka, Piechocki, Szczerbak (Dec, 2009), Balina and Juszczyk (2014). Empirical studies concerning the economic aspects of bankruptcy proceedings in Poland were conducted by the College of Business at Warsaw School of Economics (Mączyńska, 2008; Chłodnicka, 2004; Zimon \& Chłodnicka, 2013; Sojak \& Trojanek, 2010; Prusak, 2011; Morawska, 2013; Bauer, 2009; Bauer, 2013a; Bauer, 2013b; Bauer, 2014a; Bauer, 2014b; Bauer, 2014c).

Research on the costs of bankruptcy in Poland refers to the costs incurred before filing for bankruptcy, as well as the costs of proceedings.

Zimon and Chłodnicka (2013) conducted empirical studies on the impact of costs on the profitability of an economic entity. The study involved 36 construction companies in Poland. Subject of analysis was the costs of financial distress, which after declaring bankruptcy become bankruptcy costs (symptomatic bankruptcy costs). As a result of research, it was found that symptomatic bankruptcy costs are small (approx. 1\%) and profitability ratios cannot detect upcoming problems. It was also found that symptomatic bankruptcy costs are associated with the threat of loss of liquidity, incurring losses in current business operations, and the loss of creditworthiness.

Research is constantly conducted on the economic aspects of bankruptcy proceedings throughout the world, and also in Poland, by the World Bank and the findings are publisher in Doing Business Report. Doing Business:

Studies the time, cost, and outcome of insolvency proceedings involving domestic entities. The data are derived from questionnaire responses by local insolvency practitioners and verified through a study of laws and regulations as well as public information on bankruptcy systems. (...) The cost of the proceedings is recorded as a percentage of the value of the debtor's estate. The cost is calculated on the basis of questionnaire responses and includes court fees and government levies; fees of insolvency administrators, auctioneers, assessors and lawyers; and all other fees and costs ${ }^{1}$.

Research published in Doing Business Report shows that the cost of the proceedings in the years 2004-2014 consistently averaged $15 \%$ of the value of the debtor's estate ${ }^{2}$.

A survey conducted in four courts in Poland under the project "Efficiency of Bankruptcy Procedures" (Morawska, 2013) shows that bankruptcy costs are 35\% of the bankruptcy estate. Data for the study were obtained from trustee final reports or periodic statements of accounts. The results indicate a correlation between costs of the bankruptcy proceedings and the bankruptcy estate. However, in the study sample, there were cases in which the costs of proceedings were very high, despite of small bankruptcy estate funds. The results confirmed a correlation between costs of the bankruptcy proceedings and trustee remuneration. Remuneration of the trustee in relation to the costs of the bankruptcy proceedings amounted to an average of almost $5 \%$.

\section{Uncertainty of Cost Estimates in Bankruptcy in Poland}

The research focused on the costs of bankruptcy proceedings, with particular emphasis on the role of court representatives in the cost analysis. Records from 2011 of 100 cases of bankruptcy proceedings in which bankruptcy had been declared were examined.

\footnotetext{
${ }^{1}$ Retrieved from http://www.doingbusiness.org/methodology/resolving-insolvency\#cost.

${ }^{2}$ Retrieved from http://www.doingbusiness.org/Custom-Query/Poland.
} 
Empirical research has been carried out in four out of 46 district courts conducting bankruptcy proceedings in Poland. These included courts in Tarnow (three cases), Warsaw (22 cases), Katowice (26 cases), and Krakow (49 cases). Courts for the study have been selected in a targeted manner. The court in Tarnow is in a group of courts with the smallest number of bankruptcies declared. The courts in Katowice and Krakow have an average number, whereas the court in Warsaw is the court with the largest number of bankruptcies declared in Poland (about 150 annually). Documentation of all available bankruptcy proceedings in Tarnow, Katowice, and Krakow has been obtained, but documentation for missing cases has been obtained from the court in Warsaw. The assumption was to obtain a sample of 100 cases, complaint with the structure of the entire population of insolvent companies in Poland.

Double stratified selection of research sample was applied, in accordance with legal forms of enterprises insolvent during research period. In the researched sample, according to legal forms, there were 70 limited liability companies, 13 individuals engaged in economic activities, seven joint-stock companies, four registered partnerships, and six other forms of economic activity (limited partnerships, cooperatives). Such participation of enterprises, according to legal forms, is similar to the share of the total bankruptcies declared in 2011 (Coface, 2012). At the same time, the sample selection was made in accordance with the type of bankruptcy. The sample comprises 16 cases of bankruptcy with a possibility to make an arrangement and 84 cases of proceedings leading to the liquidation of the debtor's assets. The sample size corresponds to $14 \%$ of all bankruptcy cases in 2011. The accumulated research sample is an essential representative of the phenomenon countrywide. The presented research results are part of a project concerning the limitations and possibilities of using information coming from accounting documents of enterprises facing bankruptcy.

As a result of research, it has been noted that the documentation of the pre-bankruptcy proceedings included information on the planned costs of bankruptcy in 54 cases, while:

(1) In 26 cases, an interim court supervisor was not appointed, therefore, an analysis of costs of bankruptcy proceedings had not been made;

(2) In 20 cases, no information has been provided about the planned costs of bankruptcy proceedings or only some of the costs were listed (see Figure 1).

The actual costs of bankruptcy proceedings were analyzed during the next chase of research. In most cases from the study sample, no data were available about the actual costs of bankruptcy proceedings (see Figure 2). In majority of the cases, the bankruptcy proceedings which started in 2011 have not yet been finished or the documentation was not available in court (due to court procedures). However, despite of availability of documentation, in 12 cases, information about incurred costs was not provided by trustees.

Only in seven out of 18 cases, in which actual costs of bankruptcy proceedings were provided, the preliminary phase included information on planned costs. The absolute values of the actual and planned costs were analyzed (see Figure 3), and subsequently the relative difference between the actual and planned costs (see Figure 4).

As the research shows, the cost analyses in bankruptcy proceedings do not provide fully transparent information on planned and executed cost. For the preparation of cost analyses of bankruptcy proceedings, court representatives do not use the full potential of the information offered by cost accounting. Cost analyses are performed in most cases using a single variant, without division into sub-periods, and often without reference to the revenue side. In the cases studied, no analysis of deviations of actual and planned costs was performed and the reasons for the differences were not specified either. 


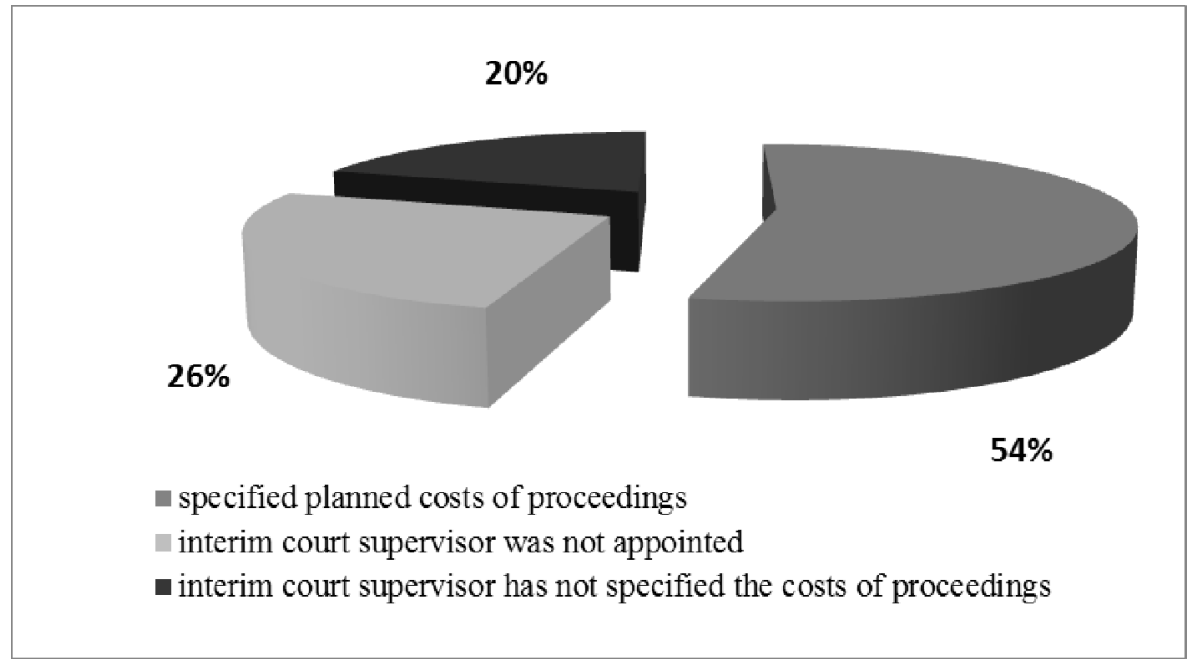

Figure 1. The share of cases with specified value of planned costs in total sample.

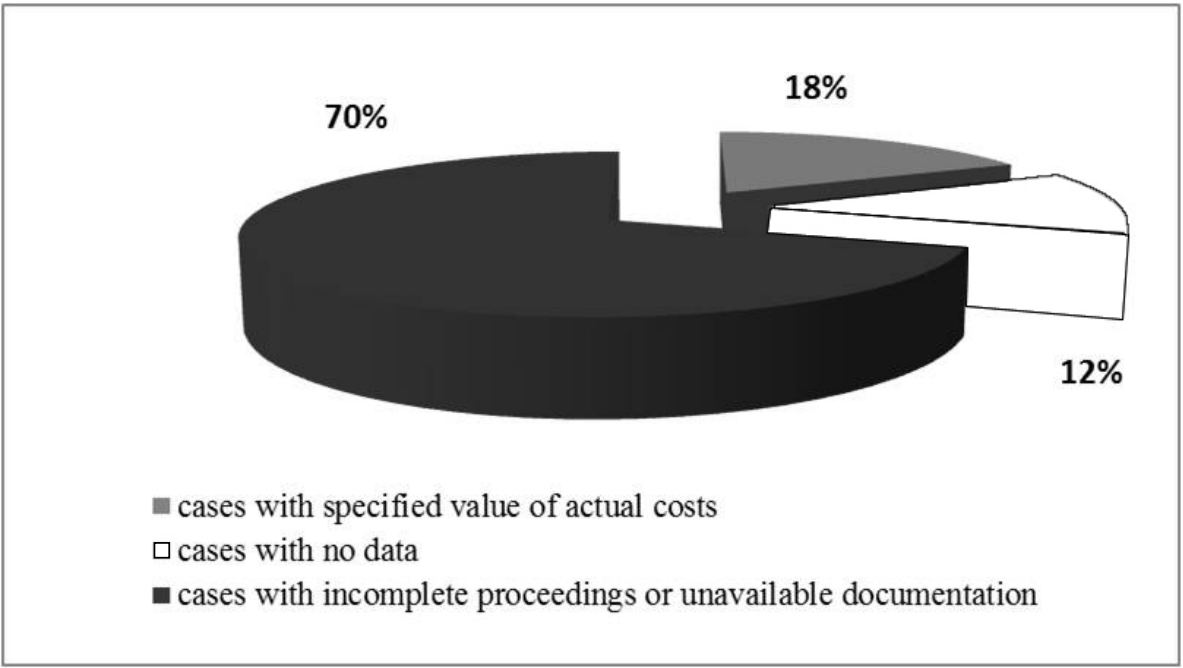

Figure 2. The share of cases with specified value of actual costs in total sample.

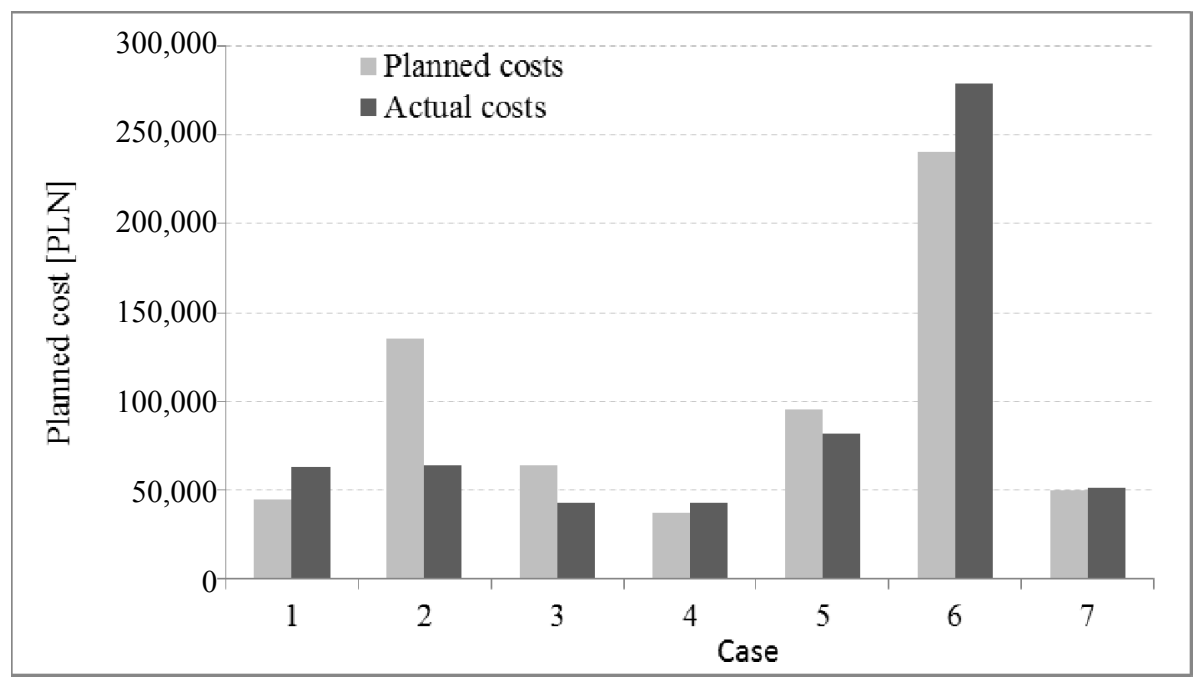

Figure 3. Comparison of planned and actual costs of bankruptcy proceedings. 


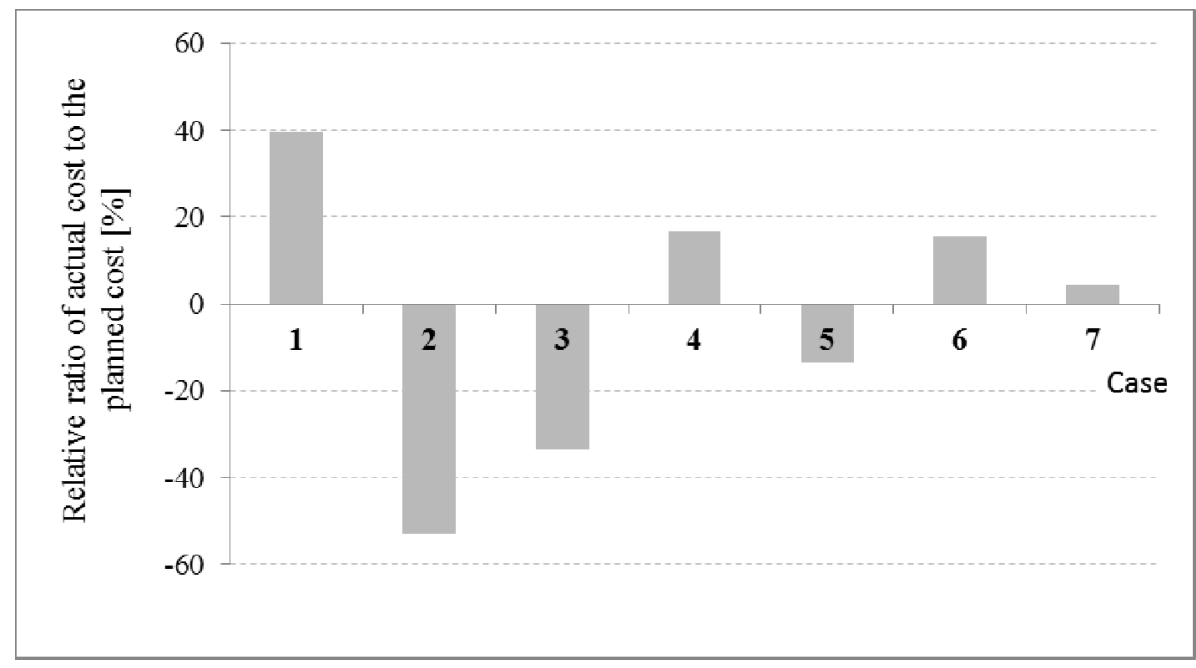

Figure 4. Statement of ratios of actual costs to the planned costs.

\section{Proposed Directions for Changes in the Cost Analysis of Bankruptcy Proceedings}

Analyses of the costs in bankruptcy proceedings are drawn up in order to decide on the feasibility of conducting insolvency proceedings and to account for the financial results after their completion. The costs are related to the size of the bankruptcy estate and any income from other sources. The difference between income and costs provides information about the ability to satisfy creditors' claims.

According to the author, in order to provide reliable information, and thus improve the functioning of the bankruptcy trial, cost accounting during bankruptcy proceedings should:

(1) Be drawn up in two versions during the planning phase - one for the costs of the proceedings leading to an arrangement and the second leading to the liquidation of the debtor's assets;

(2) Include all, logically systematized, types of costs specified in the Bankruptcy and Reorganization Law;

(3) Specify planned, estimated on the basis of a comprehensive analysis of the company at risk of bankruptcy, duration of the bankruptcy proceedings;

(4) Contain a clear reference to the revenue side (bankruptcy estate funds);

(5) Be supplemented by an analysis of planned cash income;

(6) Be divided into short periods, preferably monthly;

(7) Presenting the disposal of financial results to cover liabilities included in each category, in the order specified by the Bankruptcy and Reorganization Law;

(8) After the completion of the bankruptcy proceedings, include an analysis of deviations between actual and planned costs, along with an explanation of the reasons for these differences.

In summary, it would be advisable to develop principles for the measurement and-more detailed and transparent presentation of information about planned and actual revenues and costs in cost accounting of the bankruptcy process. Steps taken in this direction would increase the transparency of the bankruptcy proceedings, and could have a positive impact on the ability to satisfy creditors' claims.

\section{Conclusions}

Events of the last several years, such as spectacular bankruptcies of corporations or a wave of bankruptcies during the global economic crisis, have increased public interest that of theorists and practitioners of economics 
and law in the problem of bankruptcy. In Poland, actions are being taken to curb the negative effects of bankruptcy. The problem of planning, measurement, and control of the costs of bankruptcy proceedings is connected with the idea of minimizing the losses caused by the bankruptcy of an enterprise.

During research, it has been found that the current cost analyses are widely used during bankruptcy proceedings, as a basis for the court to make the decision to declare bankruptcy. This means that the court views the cost calculation prepared by interim court supervisors as essential in evaluating the feasibility to declare bankruptcy and later choosing the type of bankruptcy proceedings. Thus, the role of interim court supervisors can be considered significant, since their analyses have an impact on future activities of the in-debt enterprise. However, standards of preparation of this type of analyses have not yet been developed, and in turn this affects their detail and quality, and in many cases, rules out the possibility of their use as a tool to control costs in bankruptcy proceedings. Moreover, the role of court representatives in cost calculation of bankruptcy proceedings, from the moment bankruptcy is declared to the end of the proceedings, is minimal. The lack of calculations of deviations between actual and planned costs and the reasons for the differences deserve a negative assessment. Therefore, the role of court representatives in cost calculation of bankruptcy in Poland can be considered significant only at the initial stage of insolvency proceedings, when it can still be influential on the decision of the court. However, stating this does not automatically lead to a positive assessment of the reliability and transparency of estimates, which should also be taken into account when evaluating the role of the court representative.

It should be emphasized that the current state of implementation of the requirements for the analysis of the costs of bankruptcy proceedings must be regarded as valid in terms of the provisions of the Polish Bankruptcy and Reorganization Law. However, according to the author, the practice of preparing cost analyses, although in line with the law, does not provide fully reliable information about the costs of bankruptcy proceedings. Changes should include the development of principles for the measurement and presentation of the costs of bankruptcy. Decision-making cost accounting during bankruptcy proceedings can serve this purpose, created under the provisions of the Bankruptcy and Reorganization Law, and the experience coming from the theory and practice of cost accounting. Improving the quality of bankruptcy proceedings costs analyses would increase the role of court representatives in cost calculations.

In the days of free flow of goods, capital, and people, the transfer of difficulties between countries occurs globally. Therefore, actions to improve the efficiency of the bankruptcy proceedings in Poland, can have a positive impact on the functioning of enterprises in other countries.

\section{References}

Act of February 28, 2003. (2003). The Bankruptcy and Reorganization Law (in Polish). Dz. U. 2003 No. 60, pos. 535.

Altman, E. I. (1984). A further empirical investigation of the bankruptcy cost question. The Journal of Finance, 39(4), 1067-1089.

Altman, E. I., \& Hotchkiss, E. (2006). Corporate financial distress and bankruptcy: Predict and avoid bankruptcy, analyze, and invest in distressed debt. Hoboken, N.J.: John Wiley \& Sons, Inc.

Balina, R., \& Juszczyk, S. (2014). Forecasting bankruptcy risk of international commercial road transport companies. International Journal of Management and Enterprise Development, 13(1), 1-20.

Bauer, K. (2009). Information management in insolvency and reorganisation proceedings (in Polish). Krakow: Wydawnictwo Uniwersytetu Jagiellońskiego.

Bauer, K. (2013a). Decision calculus of bankruptcy proceedings costs (in Polish). Prace Naukowe Uniwersytetu Ekonomicznego we Wrocławiu, 289, 43-52. 
Bauer, K. (2013b). Property, plant, and equipment valuation in the financial statement of company at bankruptcy risk in Poland. In IFRS: Global rules \& local use. Proceedings from the 1st International Scientific Conference. October 16, School of Business Administration, Anglo American University, Prague. Retrieved from http://car.aauni.edu/wp-content/uploads/ IFRS_Proceedings_2013_FINAL.pdf

Bauer, K. (2014a). Fixed assets valuation in the condition of bankruptcy risk: The role of estimates. Journal of Modern Accounting and Auditing, 10(6), 652-666.

Bauer, K. (2014b). Restructuring ventures in companies at risk of bankruptcy. Competition and cooperation in the management theory and practice (pp. 155-174). Krakow: Jagiellonian University Press.

Bauer, K. (2014c). Balance sheet valuation of real estate in enterprises facing bankruptcy (in Polish). Zeszyty Naukowe Uniwersytetu Szczecińskiego, 803. Finanse, Rynki Finansowe, Ubezpieczenia, 66, 585-596.

Chłodnicka, H. (2004). Identification and systematics of bankruptcy costs (in Polish). Prace Naukowe Akademii Ekonomicznej we Wrocławiu, 1039.

Chłodnicka, H. (2005). Conditions for bankruptcy cost accounting in auditing (in Polish). Reporting and financial audit in improving the security of commercial transactions (pp. 111-119). Krakow: Centrum Rozwoju i Promocji Akademii Ekonomicznej w Krakowie.

Coface. (2012). Coface report on insolvency of companies in Poland in 2011 (in Polish). Retrieved from http://www.coface. pl/CofacePortal/ShowBinary/BEA\%20Repository/PL/p1_PL/documents/Raport_upadlosci_caly_2011_COFACE

Dec, P. (2009). Complex early-warning system for enterprises (in Polish). Risks of business operations. Select aspects (pp. 77-93). Warszawa: Warsaw School of Economics.

Doing Business Report. (2014). Retrieved from http://www.doingbusiness.org/methodology/ resolving-insolvency\#cost

Finch, B. (2012). Insolvency and financial distress: How to avoid it and survive it. London: Bloomsbury Publishing.

Gruber, M. J., \& Warner, J. B. (1977). Bankruptcy costs: Some evidence. The Journal of Finance, 32(2), 337-347.

Hennessy, C. A., \& Whited, T. M. (2007). How costly is external financing? Evidence from a structural estimation. The Journal of Finance, 62(4), 1705-1745.

Jakubecki, A., \& Zedler, F. (2010). The bankruptcy and reorganization law: Commentary (3rd ed.) (in Polish). Warszawa: Wolters Kluwer Business.

Mączyńska, E. (2008). Introduction (in Polish). Bankruptcies of companies. Selected institutional aspects (pp. 11-21). Warszawa: Warsaw School of Economics.

Marsh, D. (2010). Bankruptcy, insolvency, and the law. Brighton: Straightforward Publishing.

Morawska, S. (2013). Business owner facing bankruptcy. Diagnosis and proposal for changes in the institutional system in Poland (in Polish). Warszawa: Warsaw School of Economics.

Newton, G. W. (2010). Bankruptcy and insolvency accounting, practice and procedure (Vol. 1). United States of America: John Wiley \& Sons, Inc.

Płoch, J., Groele, B., \& Geromin, M. (2013). Bankruptcy: A chance for a clean start (in Polish). Retrieved from http://nawokandzie.ms.gov.pl/wp-content/uploads/2013/03/wokanda-16.pdf

Prusak, B. (2011). Economic analysis of corporate bankruptcy: On international scale. Warszawa: Cedewu.pl.

Skeel Jr, D. A. (1993). Markets, courts, and the brave new world of bankruptcy theory. Wisconsin Law Review, 465.

Smith, D. C. I., \& Strömberg, P. (2004). Maximizing the value of distressed assets: Bankruptcy law and the efficient reorganization of firms. Retrieved from http://www.sifr.org/PDFs/smithstromberg\%28wb2005\%29.pdf

Sojak, S., \& Trojanek, M. (2010). Account of insolvency cost (in Polish). How to start a business and not go bankrupt-Case study. Warszawa: Difin.

Stiglitz, J. E. (2004). The process of European integration and the future of Europe. Discussion Paper Series, No. 2004. 1. United Nations Economic Commission for Europe, Geneva, Switzerland.

Tokarski, A. (2010). Account of insolvency cost (in Polish). Roczniki Naukowe Wyższej Szkoły Bankowej w Toruniu, 9.

Warner, J. B., \& White, M. J. (1983). Bankruptcy costs and the new bankruptcy code. The Journal of Finance, 38(2), $477-488$.

Wędzki, D. (2012). The sequence of cash flow in bankruptcy prediction: Evidence from Poland. Theoretical Journal of Accounting, 68(124), 161-179.

Wessels, B., Markell, B. A., \& Kilborn, J. J. (2009). International cooperation in bankruptcy and insolvency matters. A joint research project of American College of Bankruptcy and Insolvency Institute. New York, N.Y.: Oxford University Press.

Zimon, G., \& Chłodnicka, H. (2013). The impact of bankruptcy costs on profitability of an economic entity (in Polish). Prace Naukowe Uniwersytetu Ekonomicznego we Wrocławiu, 291, 66-81. 